\title{
أويغن فنك حلقة وصل ما بين نيتشه وعملاقي الفكر الظواهري هوسرل ومايدغر
}

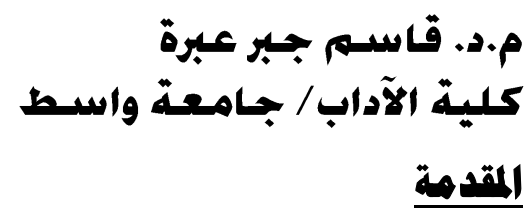

عرف القارئ العربي الفينومنولوجيا من خلال مـا ترجم عن هوسرل وهيدغر وكانت أوسـاط المتقفين تتسابق منذ ستينيات القرن المنصرم وسبعيناته على تعميق معارفها بهذين الفيلسوفين علها تستطيع هضم اثنار العاصفة التي نركها نيتشـه و هدمه السيكولوجي للقيم وللتصور ات الدينية المنرسخة بقوة في المجتمعات الثرقية و التي لم تمثلك بعد من أسباب التحضير سوى ذاكرة دينية -شعرية تعتمد سحر اللغة وجمال البيان و البلاغة لصياغة مفاهيمها عن الحياة ككلية و عن الخلود كابدية وعن القوة كمظاهرة يو مية لا بد وان تعاش بحماسة . من هنا كان الاهتمام بإرث نيتشه كبير ا حتى ان بعض زعماء السياسة و

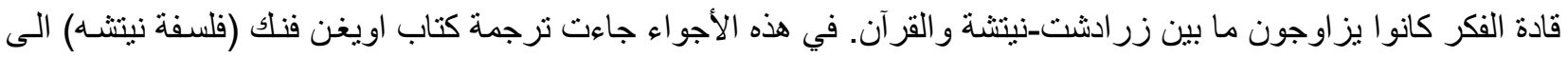
اللغة العربية على يد الياس بديوي واعتمادا على النص الفرنسي لتجعل القارئ العربي بإز اء تحليل عميق لافكار نبي العود

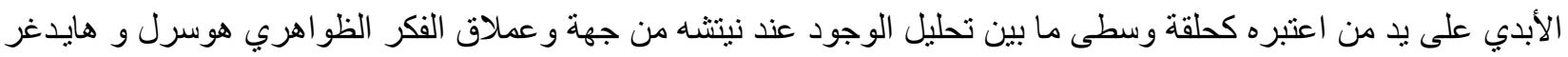

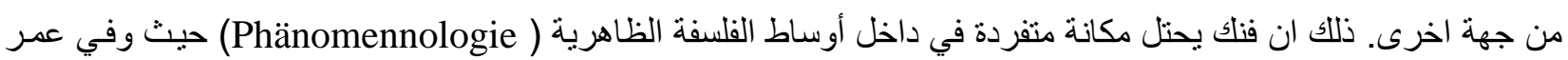
ثلاث و عشرين سنة اصبح مساعدا لهوسر وباحثا شغوفا في تأملات هوسرل الديكارتية. بيد ان القارئ العربي الذي شغف ايما شغف بكتاب اويغن فنك ظل بعيدا تمامـا عن تراث هذا المفكر اللامع وعم مجمل أفكاره عن فلسفة العالم و التجربة الوجودية و الإرث الفلاسفة مـا قبل سقراطو وعن اللعب الكوني و الميتافيزيقا والموت وتللك لعمري مواضيع تأخذ بتلابيب المثقف العربي.

ماذا يمكن ان يمثلك ارث فنك بعد ان بترجم بأجمعه او بجزء مهم منه بالنسبة للثقافة العربية؟ يمكن الإجابـة على هذا السؤال من خلال استنطاق الأزمة الجيو-سياسية التي يعيشها الفضـاء العربي وهي ازمه طاحنـة و لا شك أطاحت وستطيح بكل ثو ابت الفكر التقليدي ليس فقط بسبب صدام الحضار ات بل ان الامر ينعلق بارتجاج بنيوي اساسه فكر لم يتبلور على نحو ثابت ومنتج بعد. وناتي اهمية فنك من مزاوجته البارعة ما بين الروحي و المادي في قر اءته الفلسفية لمعضلات الفكر الكبرى كطبيعة الوجود و غائيته ومفهوم الالوهية وجدو اه ومثكلة الموت ومخرجاتها الميتافيزيقية وموقع الانسان في الكون الخغ... ان معالجـة فنك الأصيلة و البار عة لهذه المشكلات ستجعل من امر تلقيها في بيئة مأزومة مثل تلك التي تخص المحيط العربي أمراً منتجا ومحركا شديد الأهمية. هذا بالإضافة الى كوّن الثقافة العربية بكل تنو عاتها ستبقى شغوفة ايما شغف بل ومتعطشـة لتلقي افكار

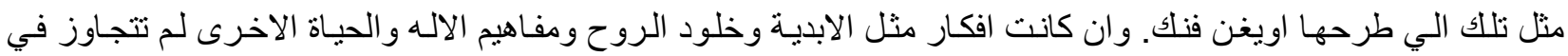
الفضاء الناطق باللغة العربية مرحلة التصورات الدو غماتيـة (Representation Dogma). فـان حضور مفاهيم عالجها فنك مثل تلك التي تخص الكون و الأبدية والموت و التجربـة الوجوديـة سيكون محركا فعالا يسمح للمثقف العربي اغناء تجربته الفكرية واستلهام السياقات التي جاء بها الاخر . فعلى سبيل المثال فان فكرة العالم المهلة تقريبا في تراث الثرق تعد عند فنك

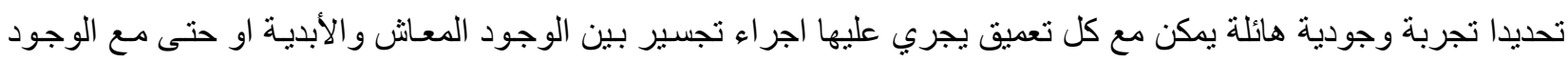
الأخروية وكذلك الامر فيما يخص فكرة اللعب الكوني والإر ادة المطلقة...

من هنـا نجد ان ترجمة وتحقيق تراث اويغن فنلك الى اللغـة العربيـة سيسهم في اغنـاء الحوار بين عـالمي الغرب و العرب وسيضيف الى المتلقي العربي اضافة حاسمة تسهح في تجسير الهوة المعرفية بين الثقافتين من خلال الذهاب الى أسس الثقافة المنتجة وجعلها تسهم في تحريك الر اكد عند المتلقي. 
يمكن ان نلاحظ إبتداءً دقة افكار اويغن فنلك حين يتعلق الامر بالكون كظاهرة. و عبر ما يربو على ثلاثين كتاباً اغلبها

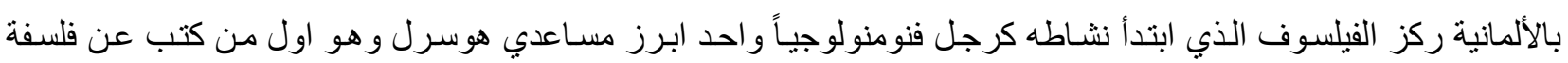

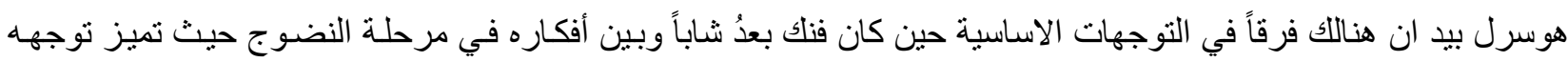

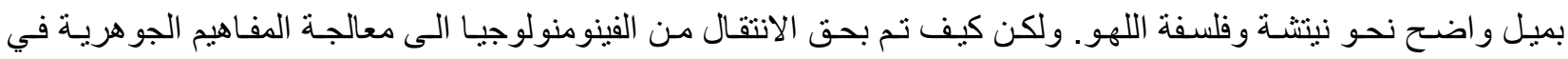
الميتافيزيقا؟

يبدو ان كلا التوجهين مرتبطان من خلال القضايا المشتركة بينهما خاصة وان المشكل الكوسمولوجي يعد هو الخبط الر ابط بين الميتافيزيقاو علم الظواهر. ذلك ان فنك كان يبحث منذ البدء عن الاساس (Grund) الذي تستق منه المفاهيم جوهر حضور ها في الفكر المعاصر وهنا تحضر عنده ثلاث مقولات هن من يوجهن مسيرة الفكر لديه: الاختز ال، التفكير و التكوين

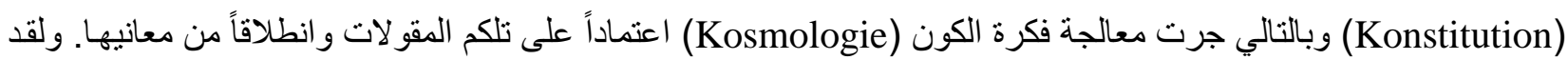

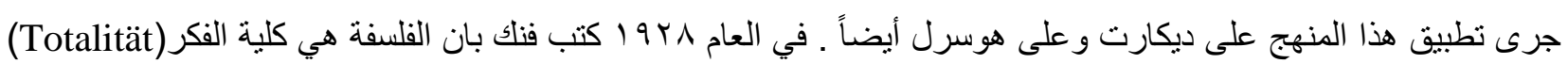

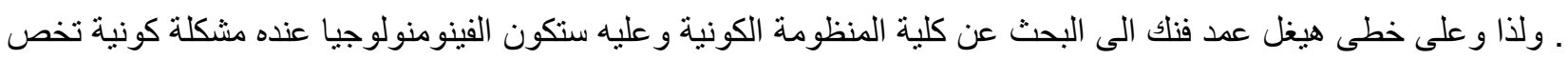
الوجود باجمعه ماهو مرئي منه و ما هو غائب عن الوعي و حنفي في طيات الوجود. ولذا يؤكد فنك على مفهوم المقاربـة

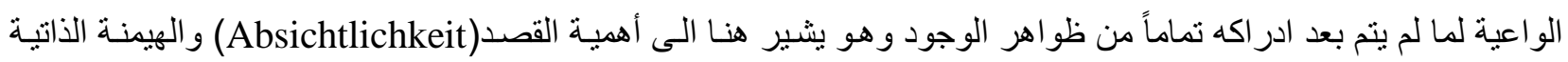
على سريرة النفس الجوانية (غير الظاهرة للاخر المتتفية في طيات للوجود) وليميز بين الموقف الطبيعي من العالم ومـا اسماه بالموقف الجوهري الذي يتطلب تر اكم للمعر ففة وفرز لأخطاء الإدر الك الحسي. يمكن القاريء العربي الافتراب من نصوص فنك عبر نيتشـة و هيدغر فالكثير من مؤلفات الاثنين مترجمة وكتب

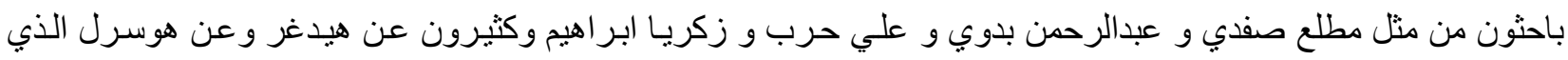

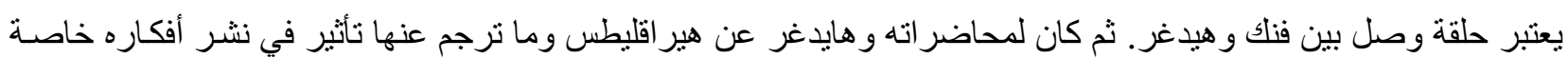

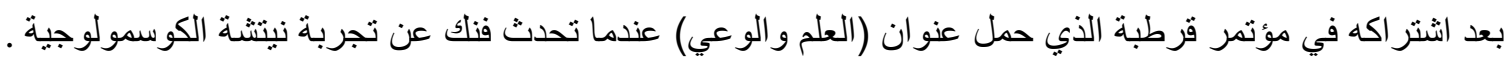

ولد اويغن فنك في / / / / / / 19 في مدينة كونستانس لعائلة يمتهن راعيها الإدارة العسكرية، وهو الرابع بين اخوته

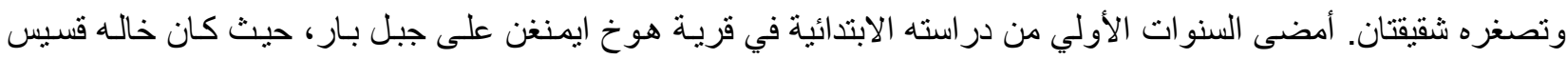

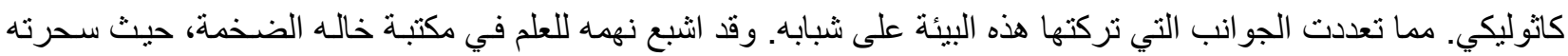

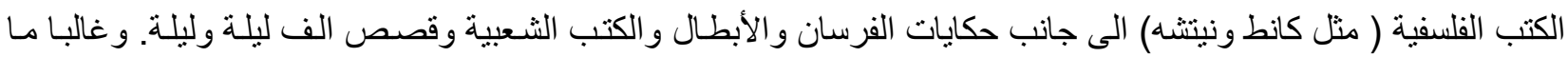
يردد حكايته كيف كان يعتاد الاختفاء مع كتاب في سرداب او مخزن مما يصعب على المرء العثور عليه. ولكن الثي الذب كان

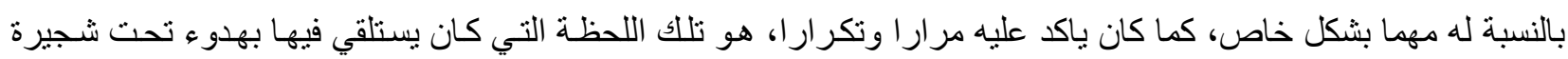

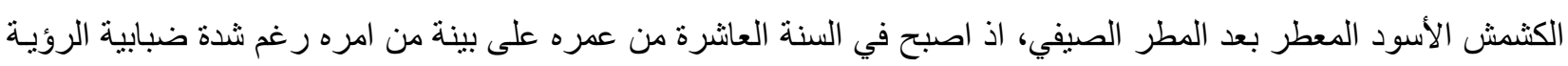
عنده: ها أنذا! لقد حدد تلك اللحظة التي تمت تجربتها بشكل مكثف على انها بداية لحياته الفلسفية. و علاوة على ذلك فان السنوات

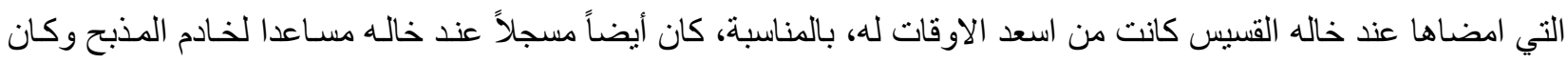

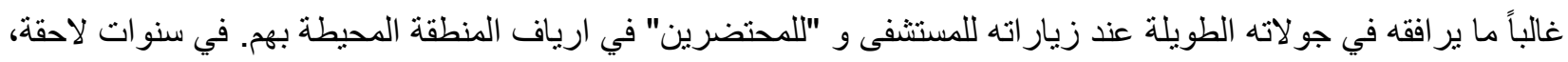

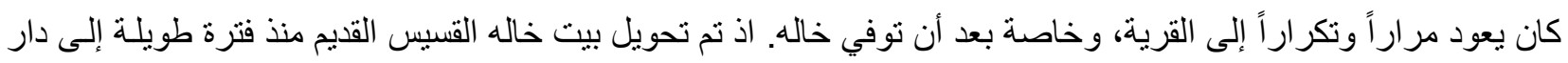
لر عاية المسنين. كان يحب التحدث عن تجارب طفوته في الغابات والمروج في المنطقة مع الأخ الأكبر وأطفال القريـة. وقد 
درسه خاله بشكل خاص، ليس فقط باللغة اللاتينية، حتى أنه عند عودته إلى كونستانس في عام 19 19 ، تم اعفائه من الصفيين الاولين ليدخل مباشرة الى المدرسة النحوية.

و بينما كان لا يز ال في المدرسة قر أ لكانط، هيوم، هيغل، نيتشه، جيوردانو برونو وكتاب عن البوذية لهايلر؛ هذه هي

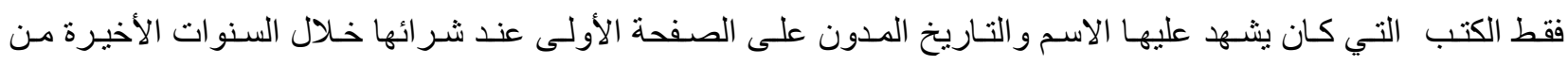

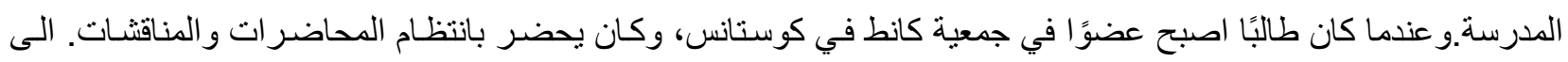

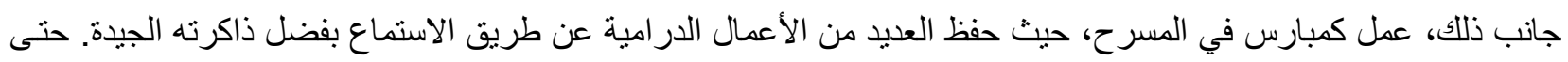

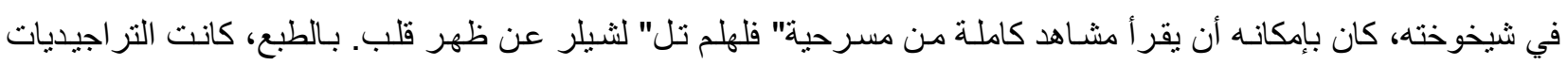
اليونانية تعني لله الكثير.

لعبت منطقة البودنسي وكذللك وجبال الألب القريبة على حد سواء دورا هاما في وقت فر اغه فمن الطبيعي عندما كان

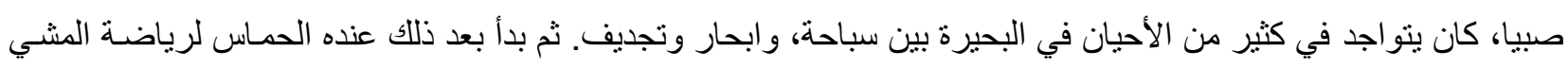

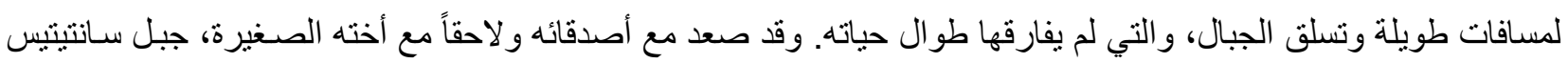

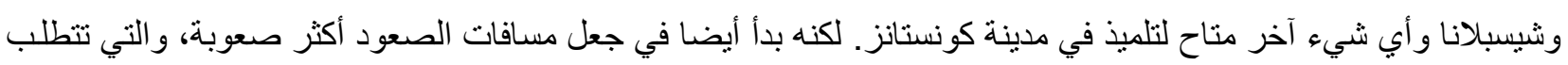

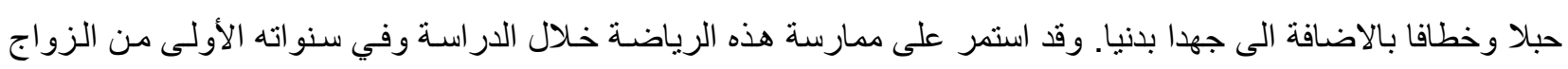

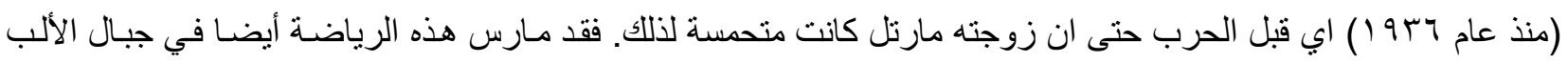

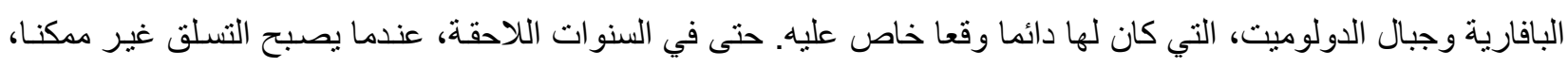

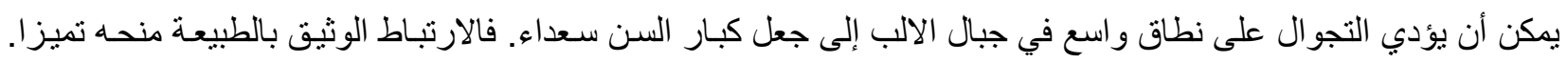
وبينما كان يتجول يتجدد فهمه للطبيعة ، فيشعر فيها بالامان.

لكن بعد تقاعد و الده في عام 19 ا انتقلت العائلة مرة أخرى إلى ميرسبرغ. لكن اويغن لم يرجع معهم. فبعد تخرجهـ

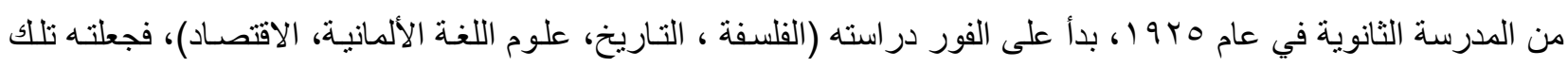

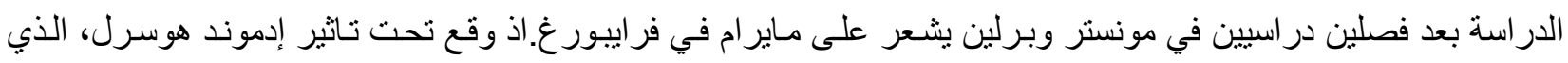

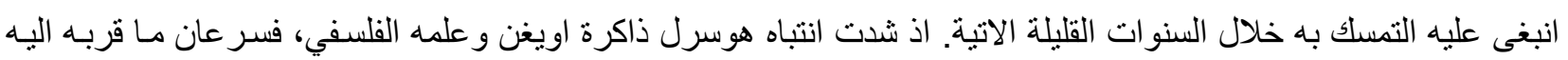

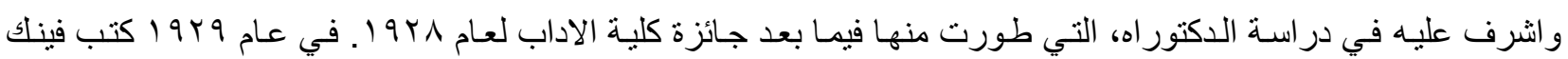
أطروحة الدكتور اه تحت اشر اف هو سرل وهايدغر حول موضوع "التصور و الصورة. مساهمات في علم ظواهر الاستحالة".

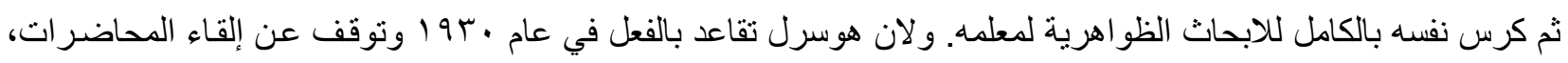
بيد ان العديد من الطلاب أر ادوا معرفة ودر اسة ظو اهر هوسرل، لذا كلف هوسرل فينك باقامة حلقات در اسية التي كانت موجه

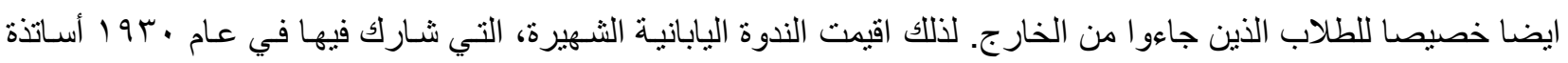
(فيما بعد) مايومي هاغا (طوكيو)، وجويتثي مياكي (سينداي)، وتومو أوتاكا (سيول)، وجيهي أوسوي (كيوتو)، اذذ عقد معهم

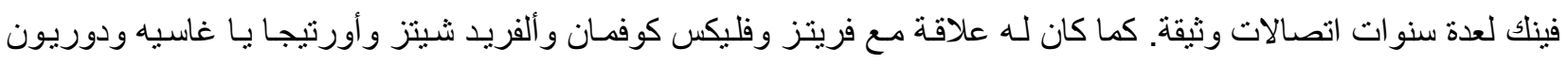

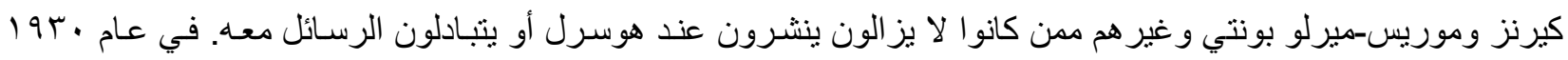
رافق فينك هوسرل في "إجازة عمل" إلى شيافاري عند البحر الأبيض المنوسط. بيد ان ساعة الحسم جاءت في عام بـ9 (: وهو ان العمل الجامعي لم يكن ممكنا، إلا إذا انفصل عن هوسرل، الذي

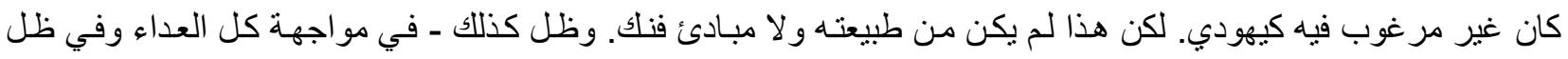

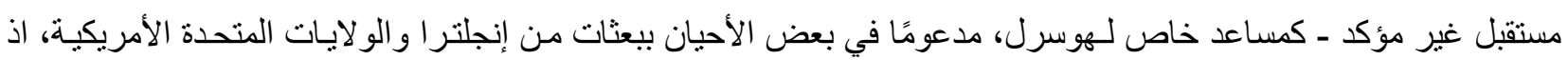


قام طلاب واصدقاء مهاجرون بحملة لصـالحه، بعد رفض الجمعية الطارئة للعلوم الالمانية اعتبـار من عام بسو ا اعطائه المزيد من المنح الدراسية.

لقد كانت سنوات من العمل الاشد كثافة وحياة فلسفية وثثقة مع هوسرل، الذي لم يتضايق بسبب سمعته الدولية، ولكنه

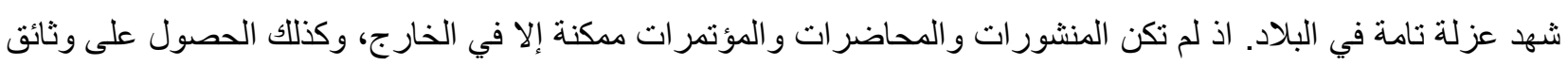

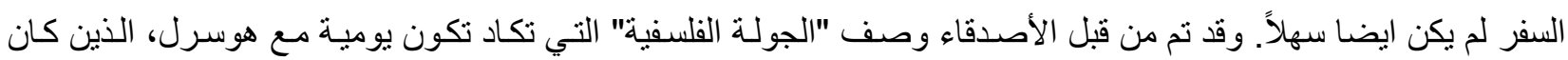

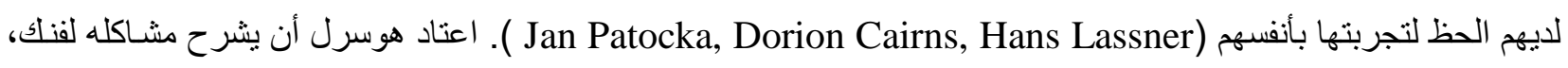

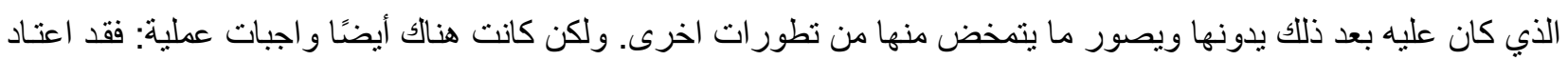

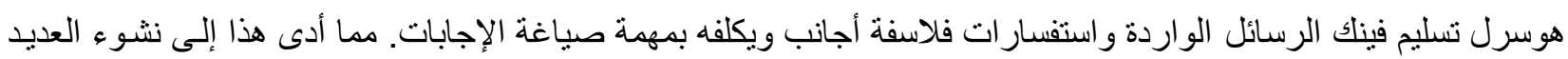

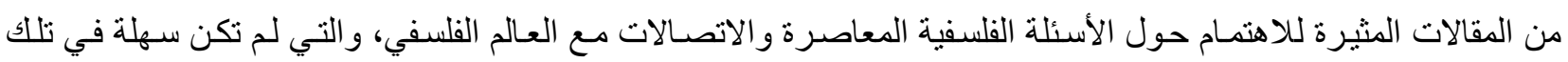
السنوات.

إن مدى اتفاق هوسرل بشكل عام مع مساعده يبدو واضحا من العديد من الرسائل إلى الأصدقاء ، على سبيل المثال،

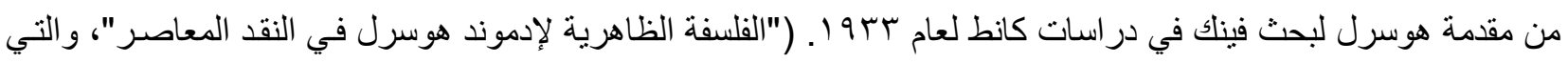

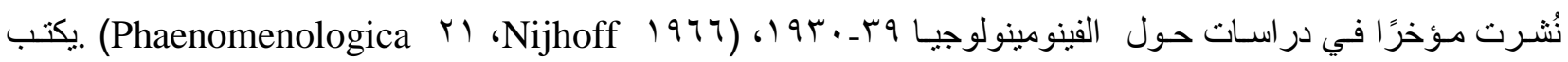

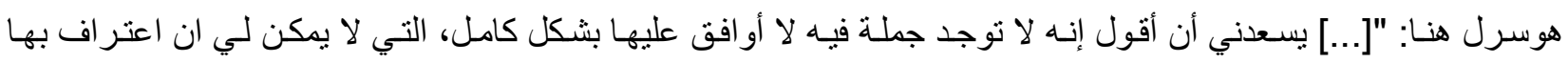

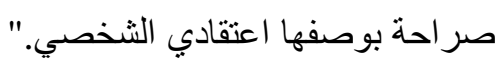
بالنسبة لاويغن فنك، كان ذلك وقتًا مفيدًا ولكن في كثير من الأحيان صعبًا، لأن الفرق الكبير في العمر، وتجربـة

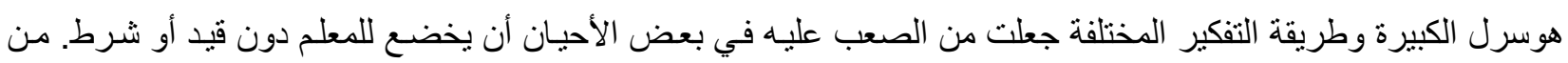

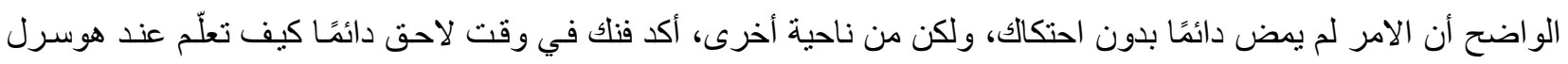

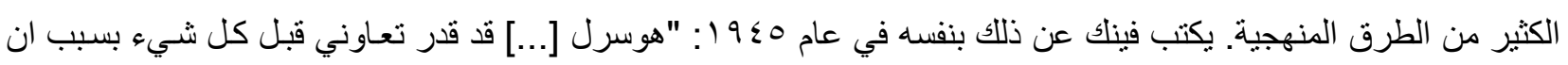
هذا التعاون كان ناقدا للغاية، وخلال هذه السنوات السبع قمت بتحرير الكثير من المخطوطات بشكل ناقد، وصغت طبن فيعات جديدة وقدمت مقترحات لتتقيح الأعمال المنشورة بالفعل بالإضـافة إلى خطط النشر . ان ارجاء العمل الفلسفي الذاتي وتقديم

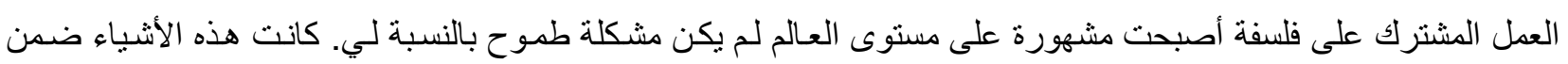

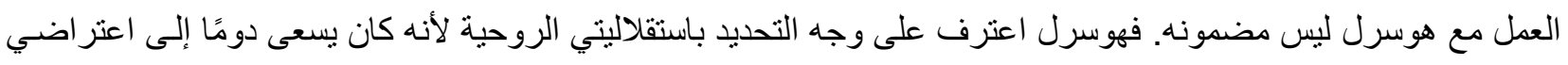

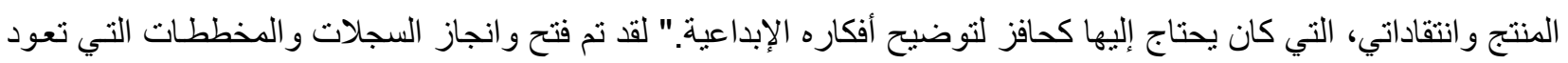
الى ذلك الوقت من قبل رونكس بروزينا (ليكسينغتون، الولايات المتحدة الأمريكية). انهت وفاة هوسرل عام ^بץ 19 هذا التعاون وطرحت سؤالا هو كيف ينبغي أن تستمر الأمور . سـاعد فينك في بـادئ الامر أرملة هوسرل والأستاذ البلجيكي هيرمان ليو فان بريدا في إنقاذ تركة هوسرل هرد الضخمة، التي جلبت إلى لوفين في بلجيكا

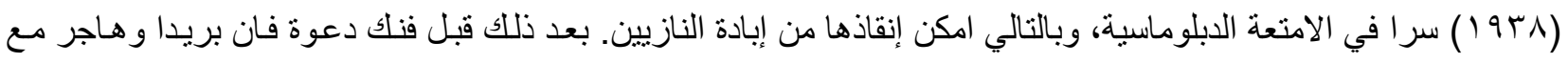

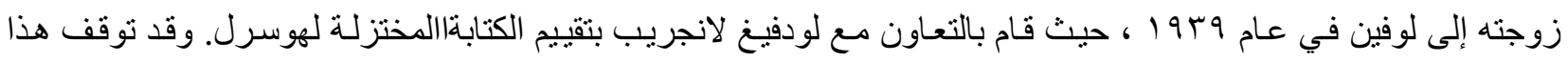

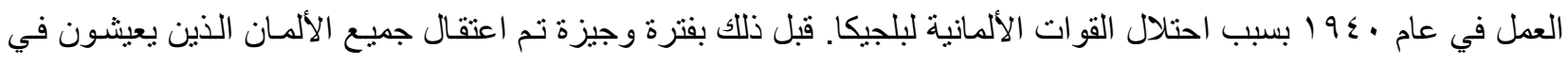
بلجيكا - بما في ذلك المهاجرين الحقبقيين - كأعضاء مزعومين في "الطابور الخامس" (لمنظمة التجسس على النازيين) وتم

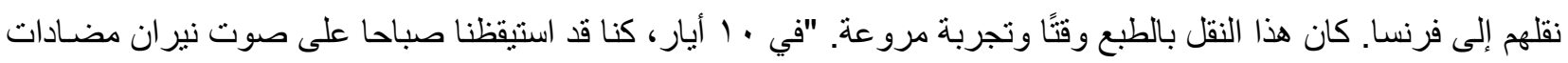

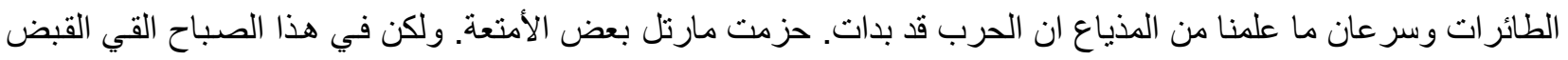


على كلانا.وتوجب علينا بلا امتنعة الذهاب الى السجن في لوفين، فانـا كنت بلا معطف و لا بطانية و لا قبعة و لا ادنى متاع،

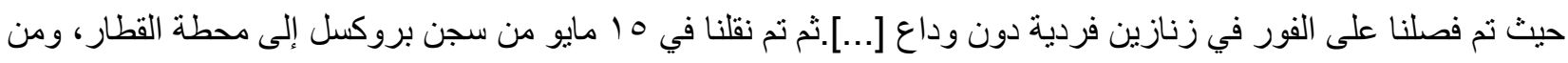

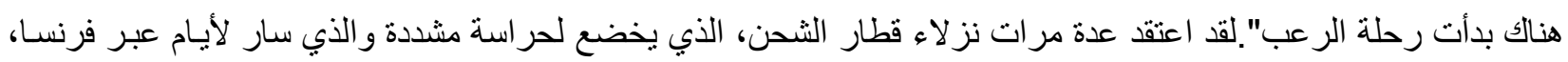

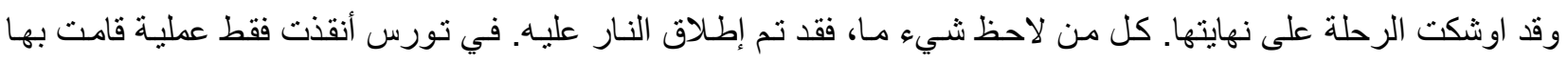
الثرطة السجناء من اعدام دون محاكمة من قبل جمهور مستعر ـ وكانت الوجهة النهائية هي المخيم الموجود في سانت سيبر فيريان

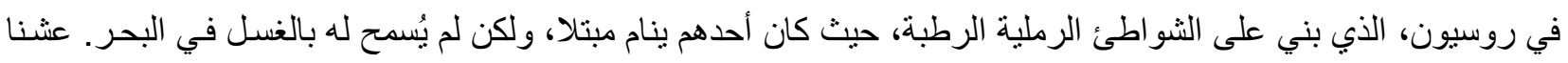

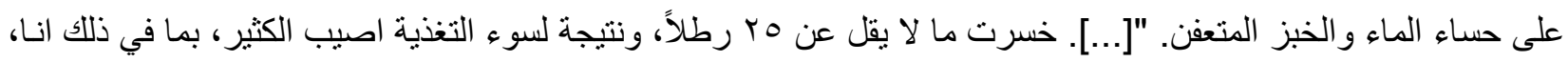
بنوع من التورم المائي،و هو تورم الاقدام بشدة." لقد تضررت صحة فينك مدى الحياة. توفي العديد من المعتقلين بسبب الجوع

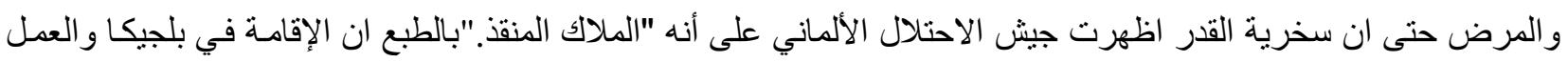

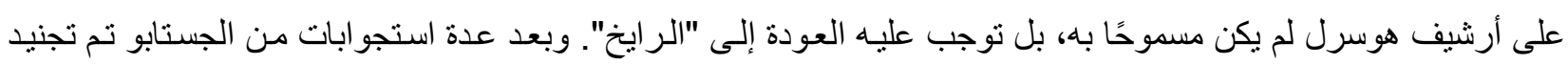

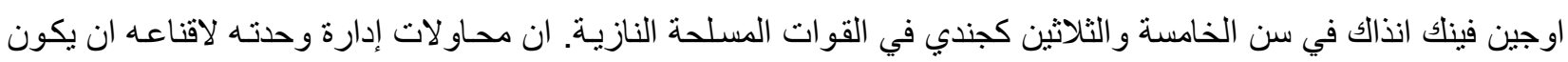

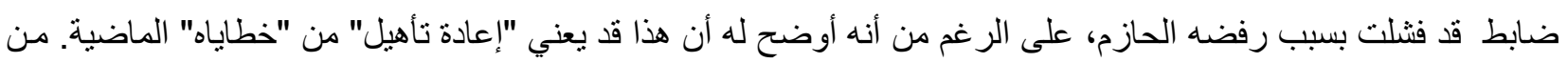

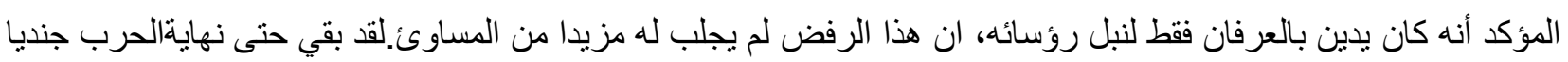

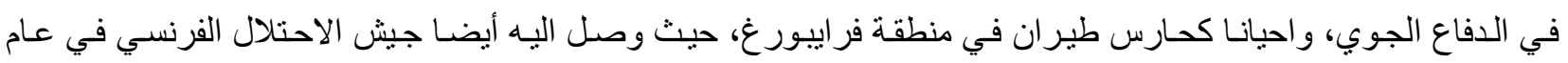
ه 9 ا ـ ومرة أخرى حالفه الحظ في مقابلة خصم نبيل: في الو اقع وصف حياته ومآسيه بالفرنسية، التي أتقنها جيداً، بمـا معناه:

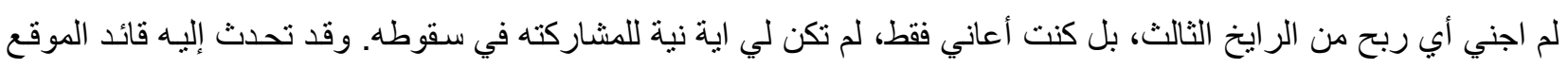

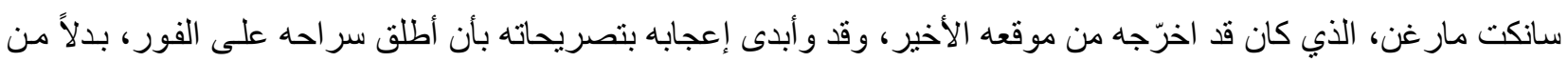

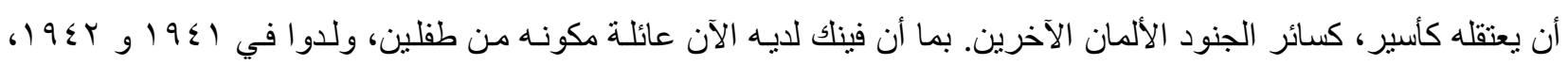

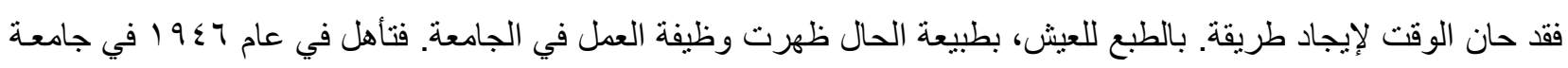

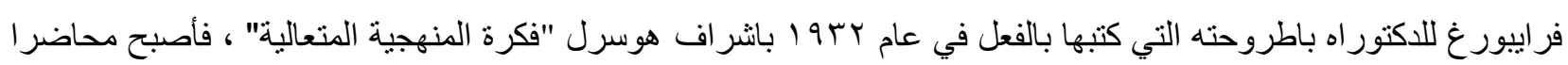
وفي عام ^§ 19 أستاذا في الفلسفة وعلم النربية. جلبت فترة ما بعد الحرب هذه أعباءً لا توصف: لبس فقط الثعور بنير الاحتلال في كل مكان، بل أيضـاً كان هنالك

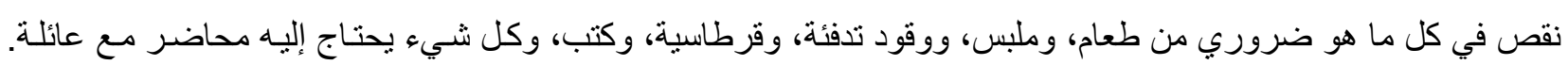

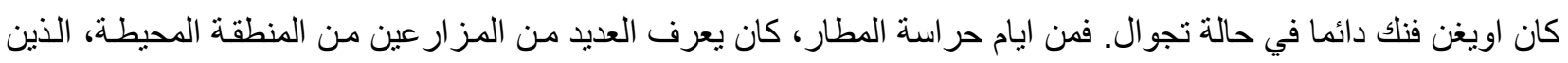

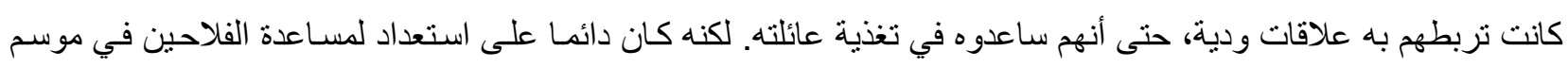

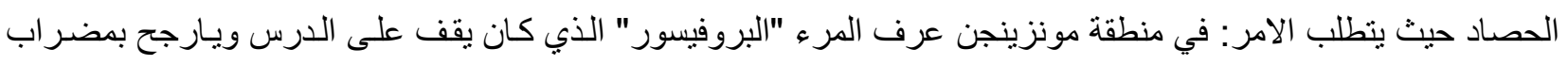

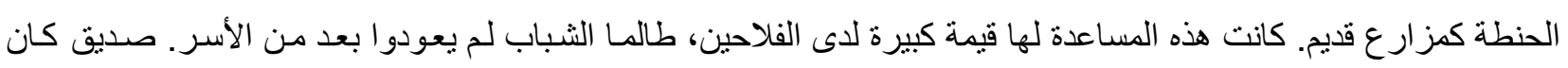

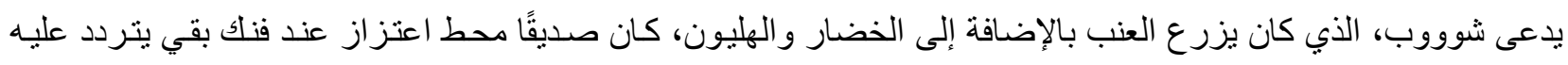

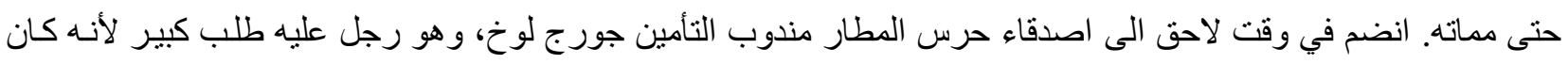
واحدا من أولئك الذين يمكنه ان يبدوا المساعدة لتعدد حرفه اليدوية. فينك كان يذهب معه الى الغابة ليحطب اي يجمع الاشجار

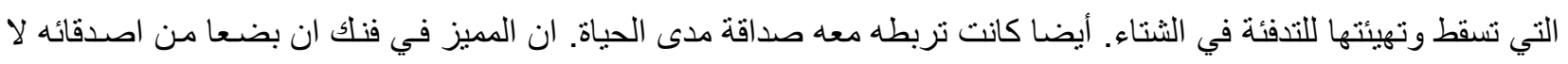

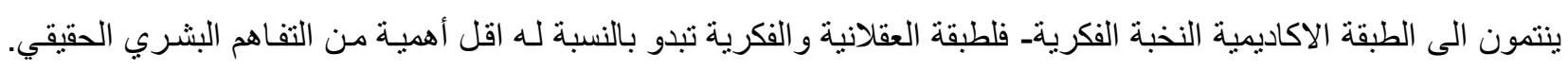

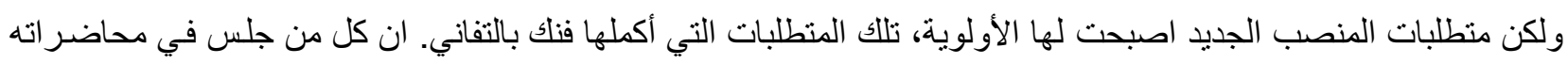

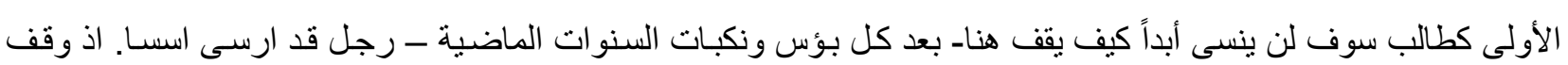

\section{$-\wedge 0 \leqslant$.}


هؤلاء الثباب اليائسين في ضياع بعد انهيار جميع "القيم" الصالحة سابقا. لقد عانو ا من بؤس الحرب، وقصف الددن، والاسر ،

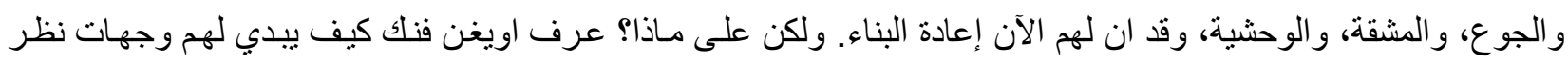
جديدة، لإعطاء مبرر الوجود لا أساس له لأظهار الطرق الممكنة التي تقود الى المستقبل. لقد شكره العديد من طلابهـ السـابقين على هذا و انهم مدينين لله طوال حياتهم.

بالإضـافة إلى ذلك شارك في العديد من الاتجاهات. ساند ابتداء من عام 19 ألـ صديق الدراسـة ألفريد ريمنشبير غر في بناء مدرسة تعليم البالغين (Volkshochschule) في فر اييور غ واستمر بنفسه لسنوات القاء دروس على سبيل المثال عن ريلكه في "مرثيات دوينو و قصائد الثعر الحر "السونيت" عند أورفيوس، ولكنه ألقى محاضر ات أيضـا عن المشـاكل التعليمية

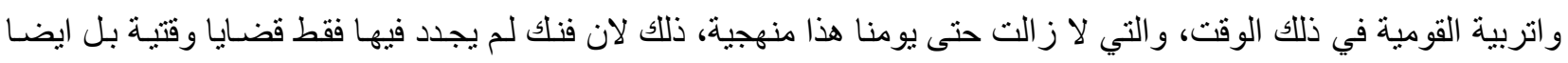

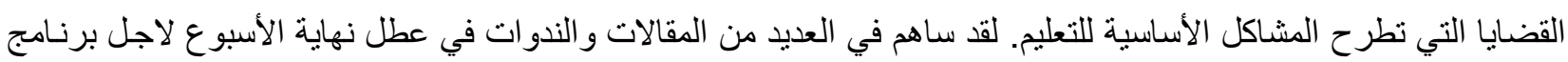
مدرسة تعليم البالغين (Volkshochschule)، وبقي يعمل في مجلس الادارة حتى وفاته. أسس عام • 190 أرشيف هوسرل فرع فراييورغ في الجامعة، واستمر العمل في تركة هوسرل بالتواصل مـع

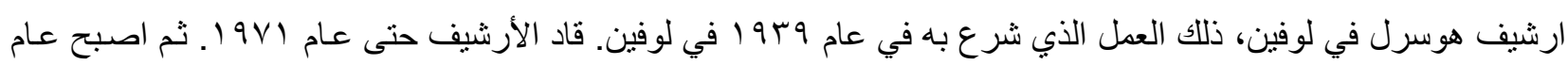

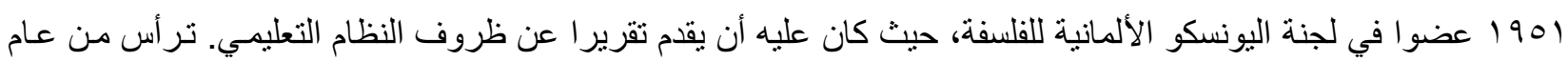

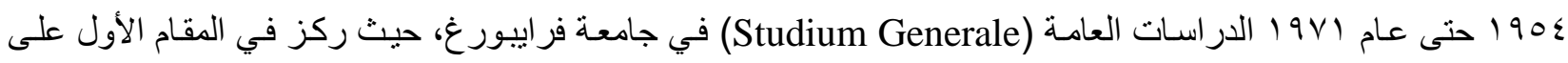

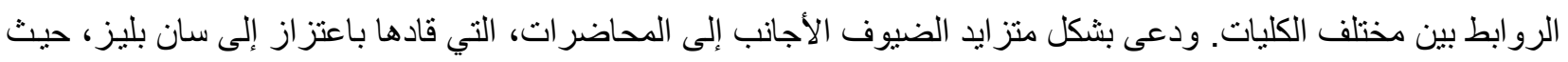

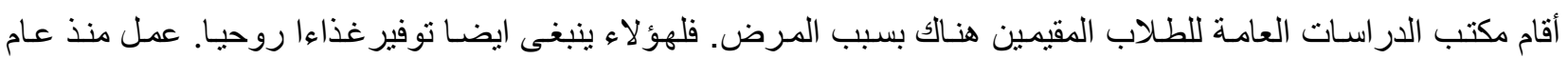

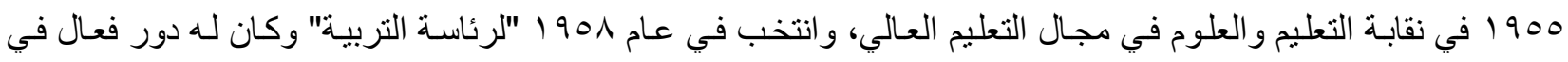

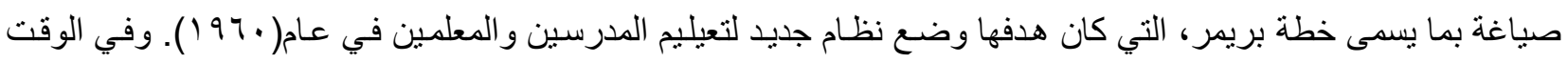

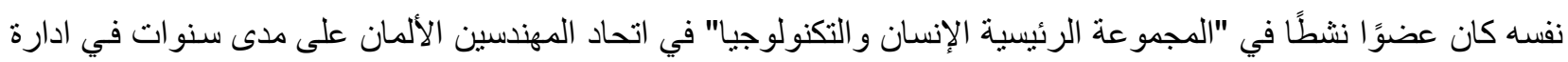
مجلس نقابة الفن في فر اييورغ، حيث كان أيضًا نائبًا للرئيس.

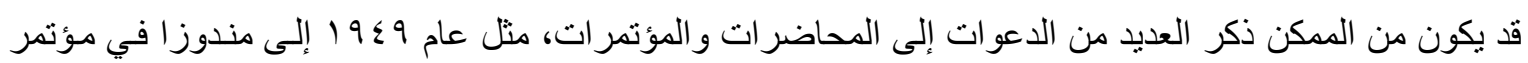

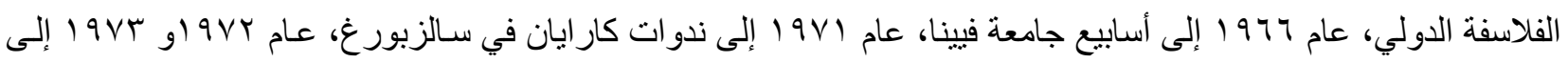

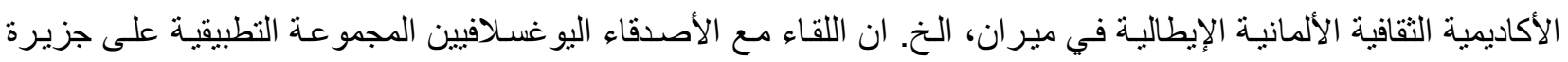

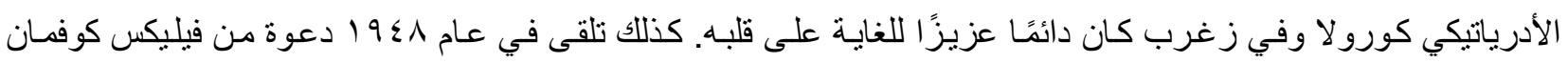
لحضور المحاضرة السنوية في المدرسة الجديدة للبحوث الاجتماعية في نيويورك وجامعة شيكاغو. لقد فثلت على ملى ما يبدو هذه فئه

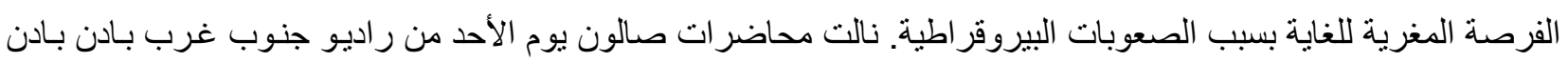

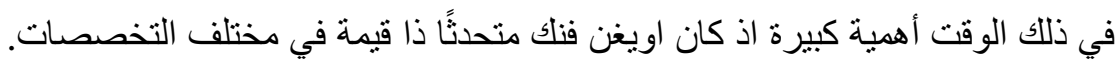

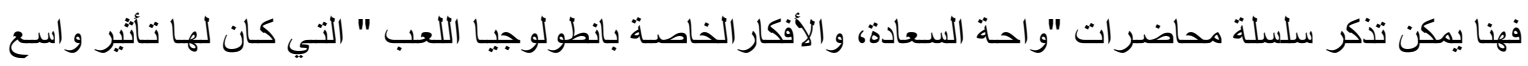

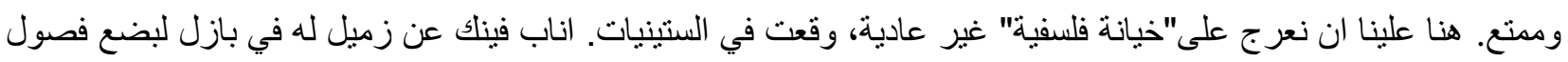

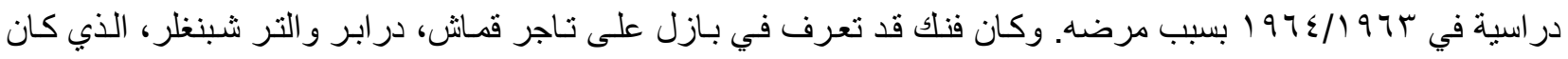

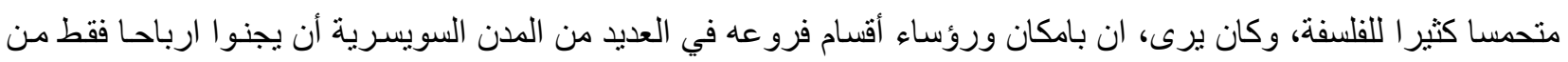

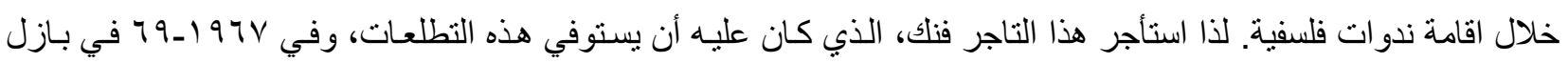

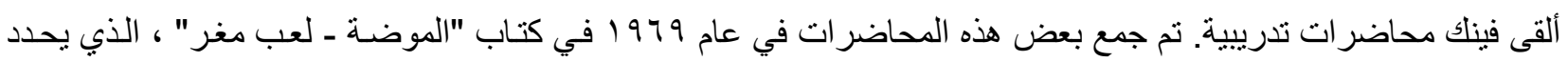


بطريقة أصلية وعميقة أفكار الفيلسوف عن الموضة. (للوء الحظ ، بسبب الخلافات بين سبنجلر وناثره، لم يتم إعادة إصدار

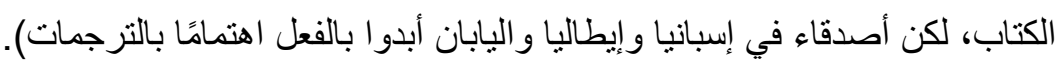

لقد برهن فينك دائما على ارتباطه بعلم الفنومنولوجيا من خلال مشاركته في المؤتمرات ذات الصلة:ابي عرض وجهة

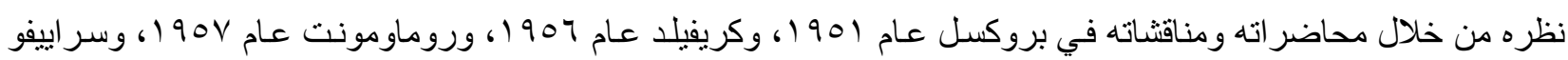

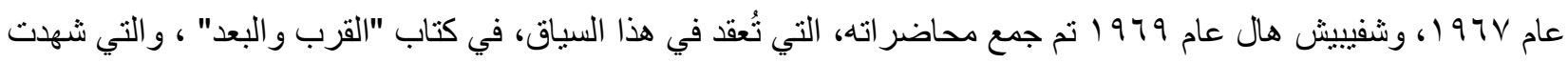
على ارتباطه مع إدموند هوسرل، الذي لم ينفه أبداً، على الرغم من أن تفكيره قد اتخذ مسارًا مختلفًا. أن هذه الطرق الأخرى كانت محل تقدير كبير، كما ينضح من النداءات التي وجىت له من قبل جامعات أخرى: عام

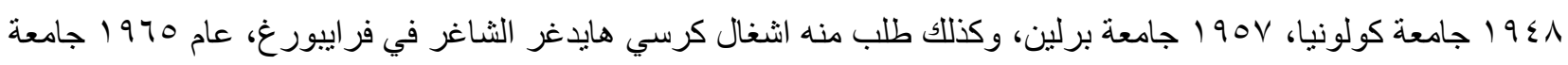

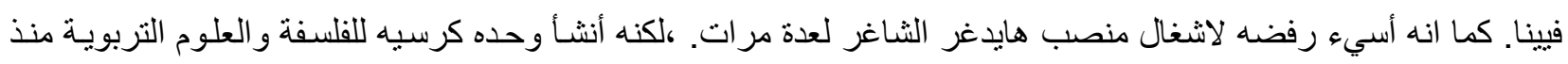

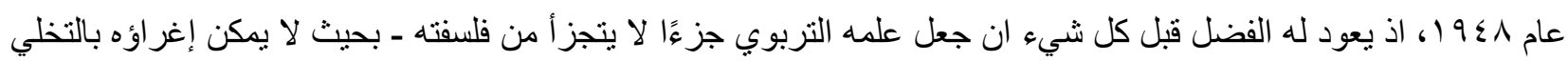

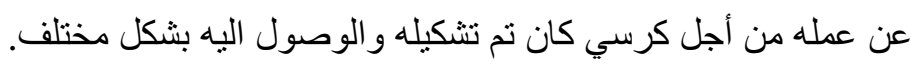

ان الكلمات لتعجز عن وصف علاقة فنك يمـارتن هايدغر. لقد استمع ودرس هايدغر من أواخر عشرينيات القرن المنصرم، وكان على اتصال وثثق معه سواء في مجال الثؤون الجامعية (تعليق هايدغر بعد الحرب) او في الحلقات الدر اسبة ونية

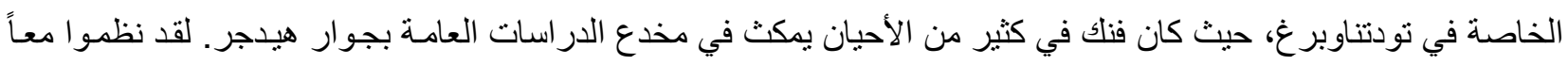

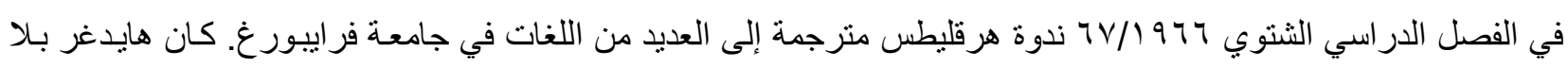

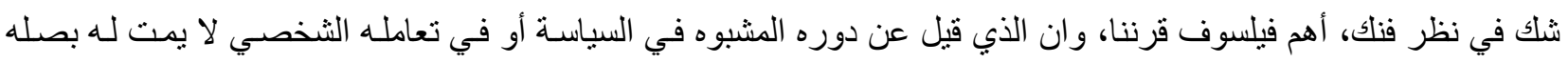

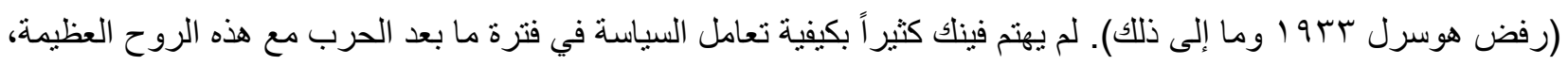
التي من الواضح لم تكن قادرة على فرض نفسها في فوضى السياسة. ربما كان هذا هو السبب وراء مواصلة فينك على العمل بعد الحرب في نركة هايدغر في الجامعة، على الرغم من

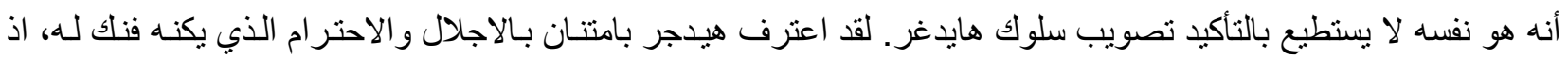

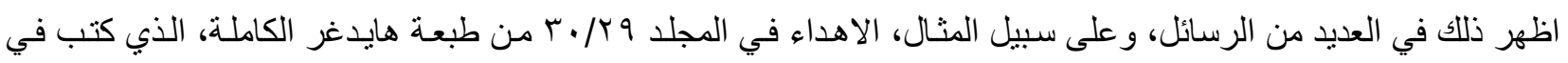
اليوم النالي لوفاة اويغن فنك. ان اجلال اويغن فلك لهايدغر كان "نعم - ولكن... ان كيفية مشاركة فيناك المؤقتًّة في الدراسات الأدبية، تتضح من مشاركته في العديد من مؤتمر ات منتدى غاربارنزر

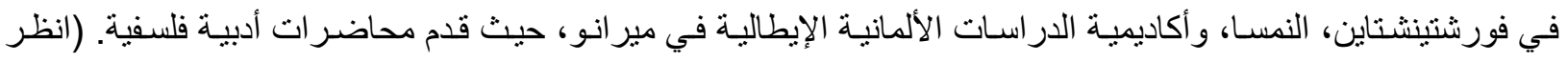

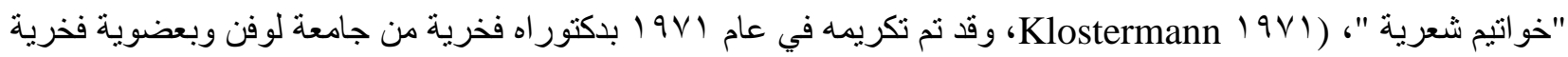
للمعهد الدولي للفلاسفة.

يصعب وصف العلاقة بين فنك و الطلاب، اذ كان من الو اضح أن نرى كم كانت كبيرة المسافة بين هذا المتفلسف على منصته ومستمعيه: فالمحاضر ات كانت صعبة لدرجة أنها تنظلب تركيز ا كبير ا من الطلاب وكذللك من المحاضر . لقد خلق هذا الجو توترا وخجل خفيا الذي بدا من الصعب كسره. لكنه فجأة بدا في الرحلات و النزهات رجل طيب القلب انبس، الذي لا يبدو

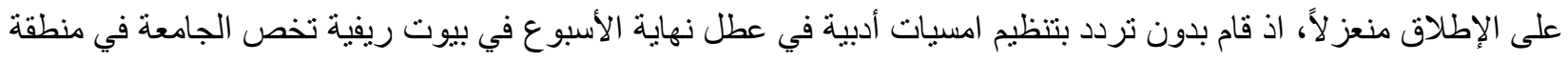

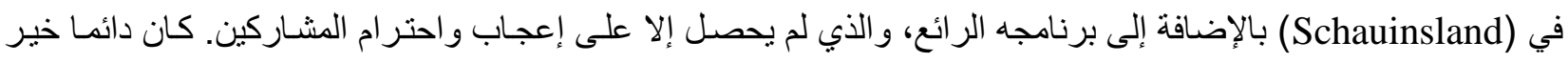

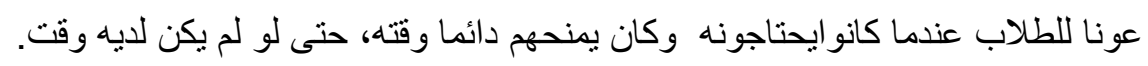


نظم حلقات دراسية في عطلة نهايـة الأسبوع حول الموضوعات التربويـة الحالية، على سبيل المثنال حول الاهمية الاجتماعية للتخطيط التربوي وخلفياته او حول مشاكل تعليم الكبار وضرورته وحول مجالات المو اضيع الأخرى التي كانت

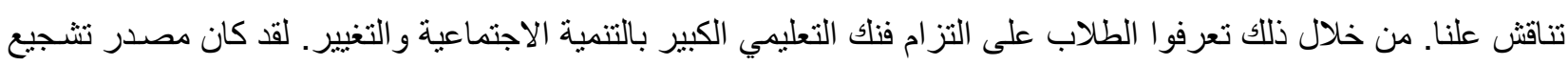
وتحدي. كان لا ير غب في الو لاء ولكن يتمنى الانفتاح في التفكير، الذي يمكن من خلاله قبول كل اقتر اح ومسـاهمة ، وتقديم

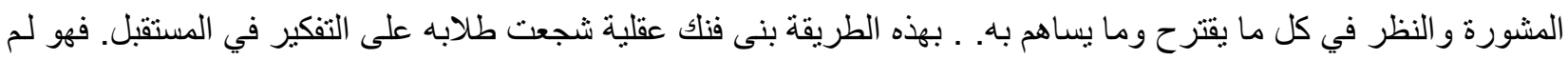

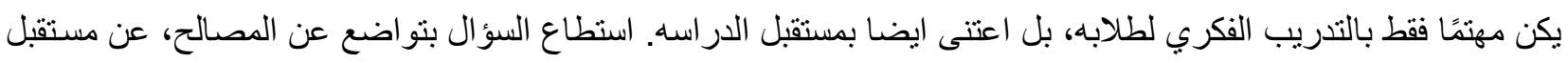

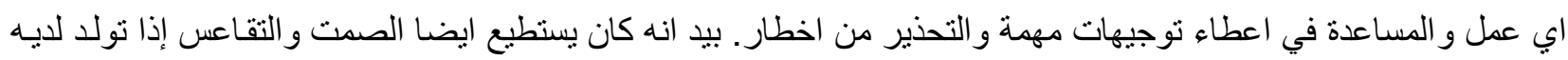

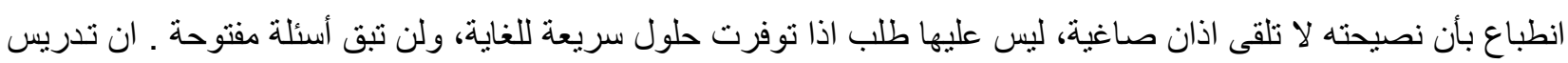

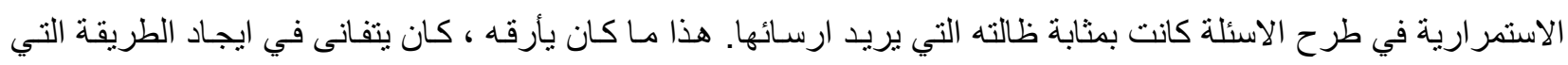

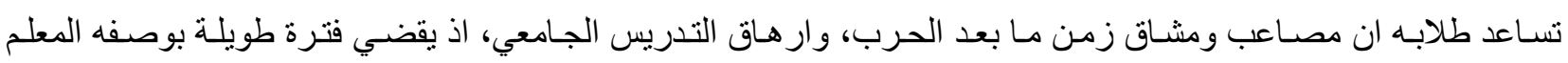

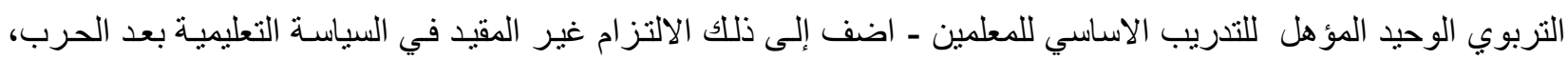

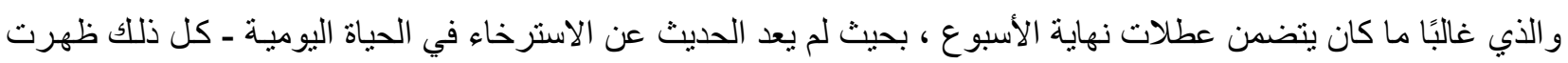

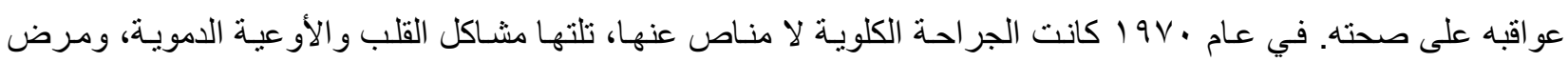

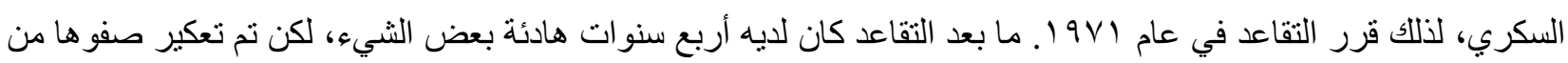

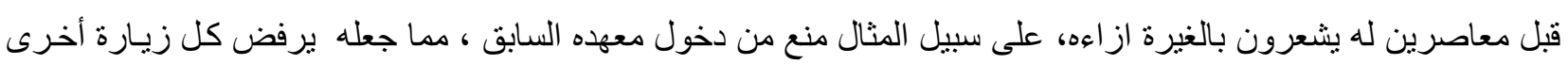

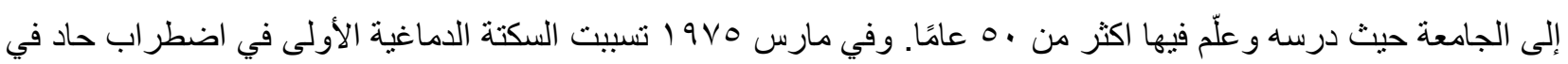

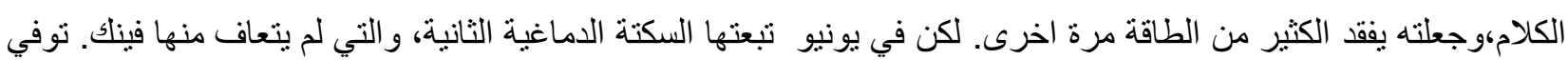

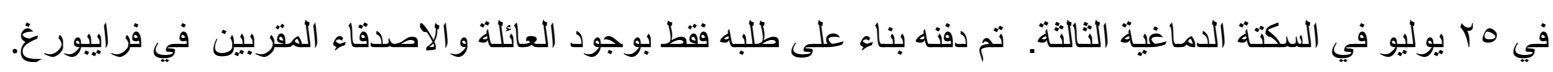

كان الثغل الثـاغل لفنك هو إثارة الحديث عن الظاهرة الأساسية للكون. ان المفهوم السائد عن العـالم هو مـا يتمخض

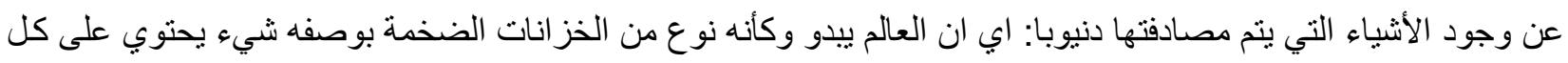

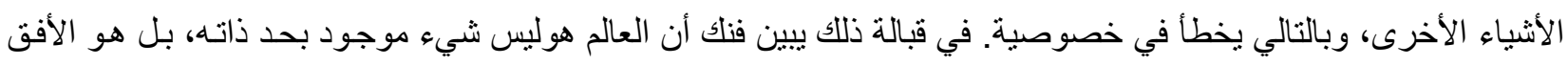

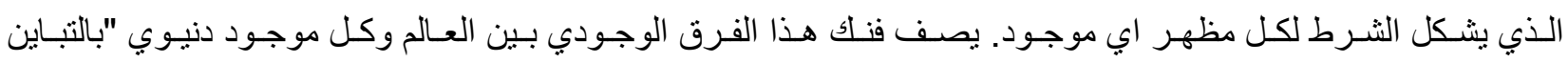

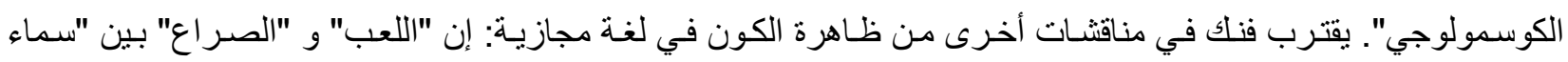

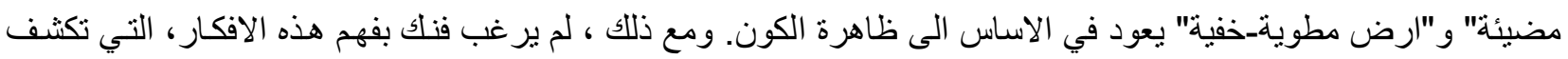

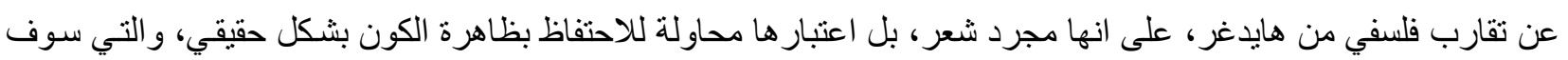

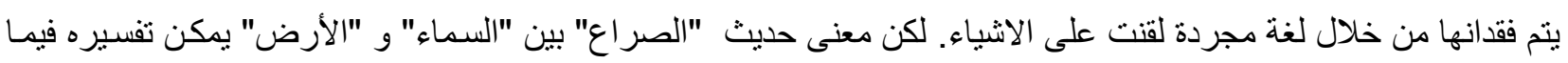

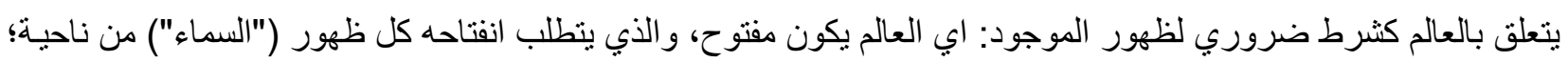
ومن ناحية أخرى فإن العالم هو أيضا شيء منواري ، فيه ينوقف ويمكث اي موجود لكي يظهر ("الأرض").

يعد اويغن فنك و احد من أهم الفلاسفة الظو اهربين في فترة مـا بعد الحرب. طور فنك في النصف الثناني من القرن

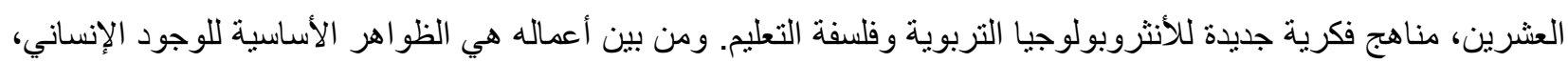
و اللعب بوصفه رمز كوني و الوجود و التعايش، الكينونه و الإنسان - عن جوهر التجربة الوجودية، والطبيعة والحريـة والعالم -

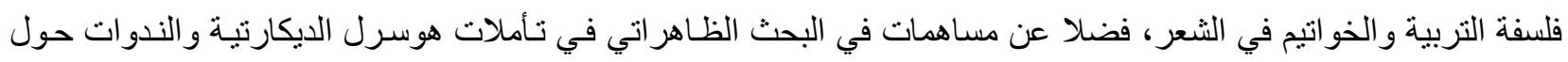
هيرقليطس التي اقيمت بالتعاون مع هايدغر. تم الإعلان في عام ه . . ب عن مشروع اويغن فنك الطبعة الكاملة من قبل النانـر 
كارل البير - من قبل محرري ستيفان كرتسل، كاترين نيسلن وهانز راينر سيب. بهذه الطبعة ينبغي ان تصبح المحاضرات و العروض التقديمية التي نشرت حتى الآن في دور النشر المختلفة والتي تعتبر غير موحدة متاحة بطبعة واحدة.

$$
\text { > الميتافيزيقا والموت شتوتغارت }
$$

يثلك الكاتب في قدرة الميتافيزيقا على تصور الموت. فمن خلال تفسير الافكار الاساسية لميتافيزيقا ارسطو،

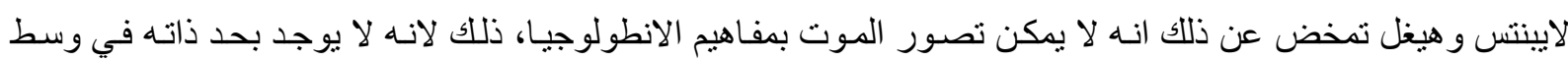

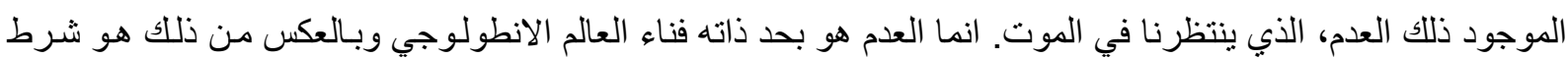

$$
\text { من خلاله نفهم شيء ما. }
$$

واحة السعادة ، فر ايبورغ $190 V$

فلسفة نيتشة، شتوتغارت، .97

اللعب بوصفه رمز كوني شتوتغارت . 197

ميتافيزيقية التربية في الفهم العالمي للافلاطون وارسطو، فر انكفورت .

هير قليطس، حلقة در اسية مع مارتين هايدغر، فر انكفورت 999 ا

الوجود و الانسان، عن جو هر التجربه الوجودية ، فر ايبورغ

الظواهر الاساسية للوجود الانساني، فر ايبوغ 1990

المسائل الأساسية للفلسفة القديمة، فورتسبورغ 1910

العالم و النهائية، فورتسبورغ ·

الافاتمة

في نهاية هذا البحث، فإننا تمكننا من خلاله، أن نسلط الضوء على معظم الجوانب المتعلقة بحياة وفلسفة اويغن فنك واهم اعماله، مما تطلب منـا اجر اء دراسـة متعمقة في ذلك الموضوع، يضـاف إلى ذلك الجوانب الشخصية للفيلسوف التي فرضت نفسها بالبحث، وكذلك عرضنا بعض المفاهييم التي تتعلق بفلسفته، واتمنى ان يكون هذا البحث حافز الطلاب العلم الذين تتمحور مو اضيع در استهم وبحوثهم حول القضايا والمشاكل التي اثار ها هذا الفيلسوف، اذ لا ننسى ان هذا الفيلسوف كان تلميذا لهايدغر وهوسرل، واستطاع فيما بعد ان يشق طريقه ويرسم ملامح فلسفته الخاصة بـه، اذ تلخصت في مجمو عـة كبيرة من الكتب اهمها على سبيل المثال "اللعب بوصفه رمز كوني" وكذلك "واحة السعادة " "الميتافيزيقا والموت والقائمة تطول. ان اويغن فنلك يرى اللعب قديما كقدم الانسانية ـ لقد اتخذ من فلسفة اللعب ظاهرة اساسية للوجود الانسـاني. واعتبر اللعب بمثابـة سمة أساسية للإنسان، الذي يعبر فيها عن تفاعله الاجتماعي، ويستكثف إمكانيات العيش معا ويضع لذلك قو اعدا. "يظهر لنا

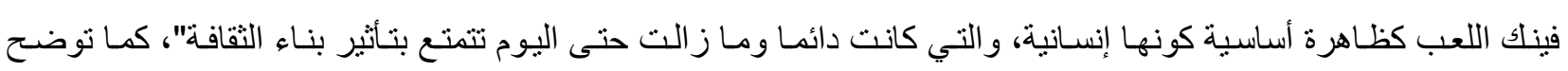
الدكتوره. أنيتة هيلت ، باحث مشارك في مركز أبحاث اويغن فنك الدولي لعلم الأنثروبولوجيا والفلسفة الاجتماعيـة في ماينس.

"إن أساليبه ومناهجه لا نز ال لحد يومنا هذا مثيرة للاهتمام ومهمة لعلم التربية ".

يقوم مشروعي على اختيار اهم اعمال فنك التي لم تترجم الى اللغة العربية بعد تحقيقها وبتقديم إضـاءات وشروحات للغامض منها بمساعدة زملائي من المختصين بالفلسفة الغربية الحديثة ومن ثم نشر هذا المنتج و إقامـة حلقات نقاشية للتذكير

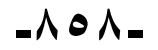


بإسهامات فنلك وارتباط فلسفته بآر اء هايدغر وميروبونتي وكذلك شروحاته لتأملات هوسرل وحلقته الدر اسبة التي اجر اهاهـا العام VT 97 بصحبة هايدغر عن هير اقليطس في جامعة فر ايبورغ. كما سأعمل من خلال تعمقي في تراث فنك ومن موقعي

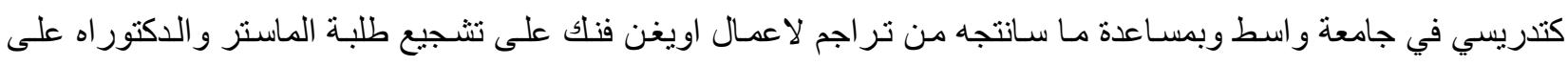
الخوض في تراث هذا الفيلسوف. مدخل الى فينومينولوجيـا الكون عند اويغن فنك. لذا اوصـي بتكثيف ودعم الجهود لترجمـة موروث هذا الفيلسوف الذي لا يقل اهمية عن عمالقة الفلسفة الالمانية هوسرل هايدغر او كاط.

- $\quad$ Annette Hilt / Cathrin Nielsen (Hg.): Bildung im technischen Zeitalter. Sein, Mensch und Welt nach Eugen Fink. Freiburg/München r... .

- $\quad$ Anselm Böhmer (Hg.): Eugen Fink: Sozialphilosophie - Anthropologie - Kosmologie - Pädagogik Methodik. Würzburg: Königshausen und Neumann ץ . . ^ Anselm Böhmer: Kosmologische Didaktik: Lernen und Lehren bei Eugen Fink. Würzburg: Königshausen und Neumann r..r

- $\quad$ Hans Rainer Sepp und Amin Wildermuth (Hrsg.): Konzepte des Phänomenalen. Heinrich Barth Eugen Fink - Jan Patočka. Orbis Phaenomenologicus. Perspektiven. Neue Folge rr. Königshausen \& Neumann, Würzburg $r \cdot 1 \cdot$.

- Hartmut Meyer-Wolters: Koexistenz und Freiheit. Eugen Finks Anthropologie und Bildungstheorie, Würzburg 199r.

- Helmuth Vetter (Hg.): Lebenswelten. Ludwig Landgrebe, Eugen Fink, Jan Patocka. Mit einer Auswahl aus dem unveröffentlichten Briefwechsel zwischen Landgrebe und Patocka. Frankfurt a. M. r..r.

- $\quad$ Katharina Schenk-Mair: Die Kosmologie Eugen Finks. Würzburg $199 \mathrm{~V}$

- Matthias Burchardt: Erziehung im Weltbezug - Zur pädagogischen Anthropologie Eugen Finks. Würzburg r...

- $\quad$ Ronald Bruzina: Edmund Husserl and Eugen Fink: beginnings and ends in phenomenology, 19 -

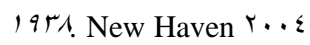

- $\quad$ Stephen Wirth: Mensch und Welt: die Anthropo-Kosmologie Eugen Finks. Mainz 1990. 